PERM JOURNAL OF PETROLEUM AND MINING ENGINEERING ВЕСТНИК ПНИПУ. ГЕОЛОГИЯ. НЕФТЕТАЗОВОЕ И ГОРНОЕ ДЕЛО

ISSN 2224-9923

Volume/ Tom 19 №2 2019

http://vestnik,pstu.ru/geo/

UDC 622.276+550.83:622.241:004

Article / Статья

(C) PNRPU / ПНИПУ, 2019

\title{
ANALYSIS OF THE EXISTING AND DEVELOPMENT \\ OF NEW SOFTWARE PACKAGES FOR PROCESSING AND INTERPRETING OF GEOPHYSICAL WELL LOGGING DATA
}

\section{Aleksandr V. Shumilov}

Perm State National Research University (15 Bukireva st., Perm, 614068, Russian Federation)

\section{АНАЛИЗ СУЩЕСТВУЮЩИХ И РАЗРАБОТКА НОВЫХ ПРОГРАММНЫХ КОМПЛЕКСОВ ОБРАБОТКИ И ИНТЕРПРЕТАЦИИ ИНФОРМАЦИИ О ГЕОФИЗИЧЕСКИХ ИССЛЕДОВАНИЯХ СКВАЖИН}

\section{А.В. Шумилов}

Пермский государственный национальный исследовательский университет (614990, Россия, г. Пермь, ул. Букирева, 15) Received / Получена: 30.04.2019. Accepted / Принята: 01.06.2019. Published / Опубликована: 28.06.2019

\section{Key words}

oil and gas geophysics, geophysical well survey methods, monitoring well technical condition, acoustic logging, waveform acoustic logging, well defectoscopy, acoustic cement bond logging, radiometric cemen bond logging, profile logging, software, compression algorithms, software packages comparison, software architecture, software object model, software component model, wavelet transform.

\section{Ключевые слова:}

нефтегазовая геофизика, геофизические методы исследования скважин, контроль технического состояния скважин, акустический каротаж, волновой акустический каротаж, дефектоскопия скважин, акустическая цементометрия, радиометрическая цементометрия, профилеметрия, программное обеспечение, алгоритмы сжатия, сравнение программных комплексов, архитектура программного обеспечения, объектная модель программы, компонентная модель программы, вейвлетпреобразование.
At present there exists many packages for interpreting geophysical well logging data, permitting to solve geological tasks and monitor well technical condition. For well condition status evaluation a complex of geophysical methods is used, including acoustic, radioactive, electromagnetic and other methods.

This article makes a comparative analysis of possibilities of the existing well logging software packages for monitoring well technical condition. In the course of the studies we have in details analyzed both packages by other developers and own modular system for processing and interpreting geophysical well logging data («SONATA»), reviewing possibilities of the programs at all stages of data processing and interpreting: various data formats support, material quality evaluation according to industry standards, step-by-step processing support, preprocessing, signal parameters determination, calculation of physical mechanical properties and other parameters, processing data of various acoustic, radioactive, electromagnetic methods and profile logging. Advantages of «SONATA» system in comparison to the existing program complexes are demonstrated.

Internal arrangement of «SONATA» system and utility software packages accompanying the program package is analyzed in details. Major peculiarities of «SONATA» system software architecture are presented: object and component models reflecting internal arrangement of interpreting complex. From the companion programs in details are analyzed geophysical well logging data compression packages, their evolution and algorithms developed for compression.

Many years of experience of using geophysical well logging data processing and interpreting modular system «SONATA» by geophysical organizations in Russia and former USSR have demonstrated that the software complex is in demand with oilfield servicing organizations, permitting them to solve the complete range of tasks on monitoring well technical conditions, providing ergonomic interface and convenient set of tools for generation of resulting conclusions and documents.

В настоящее время существует множество пакетов интерпретации данных геофизических исследований скважин (ГИС), позволяющих решать геологические задачи и осуществлять контроль технического состояния скважин. Для оценки состояния скважин используют комплекс геофизических методов, включая акустические, радиоактивные, электромагнитные и др.

В статье выполнен сравнительный анализ возможностей существующих программных комплексов ГИС для контроля технического состояния скважин. Детально проанализированы как пакеты других разработчиков, так и собственная модульная система обработки и интерпретации данных геофизических исследований скважин («СОНАТА»). Рассмотрены возможности программ на всех этапах обработки и интерпретации: поддержка различных форматов данных, оценка качества материала в соответствии с отраслевыми стандартами, поддержка пошаговой обработки, предварительная обработка, определение параметров сигнала, расчет физико-механических свойств и других параметров, обработка данных различных акустических, радиоактивных, электромагнитных методов и профилеметрии. Показаны преимущества системы «СОНАТА» по сравнению с существующими программными комплексами.

Подробно проанализировано внутреннее устройство системы «СОНАТА» и служебных пакетов программ, сопровождающих указанный программный комплекс. Представлены важнейшие особенности программной архитектуры системы «СОНАТА»: объектная и компонентная модели, отображающие внутреннее устройство интерпретационного комплекса. Из сопутствующих программ детально проанализированы пакеты сжатия скважинных геофизических данных, их эволюция и разработанные для сжатия алгоритмы.

Многолетний опыт использования модульной системы обработки и интерпретации данных геофизических исследований скважин «СОНАТА» в геофизических организациях России и ближнего зарубежья показал, что программный комплекс является востребованным в нефтесервисных организациях, позволяя решать полный спектр задач контроля технического состояния скважин, предоставляя эргономичный интерфейс и удобный набор средств для формирования итоговых выводов и документов.

Aleksandr V. Shumilov - PhD in Engineering, Associate Professor of the Department of Geophysics (tel.: +007 951 951 11 22, e-mail: shum5011@gmail.com).

Шумилов Александр Владимирович - кандидат технических наук, доцент кафедры геофизики (тел.: +007 95195111 22, e-mail: shum5011@gmail.com). 


\section{Introduction}

At present a variety of programs for geophysical well logging data interpretation [1-5] exists, permitting to solve geological tasks and monitor well technical condition. For evaluation of well condition a complex of methods is used [1, 4, 6-12], including acoustic, radioactive, electromagnetic and other methods.

In this respect it is important to perform comparative analysis of possibilities of the existing logging software packages designated for monitoring well technical condition. It is necessary to review program possibilities at all stages of processing and interpreting: various data formats support, material quality evaluation according to industry standards [13], step-by-step processing support, preprocessing [14], signal parameters determination [15, 16], calculation of physical mechanical properties and other parameters [6], processing data of various acoustic, radioactive, electromagnetic methods [17, 18] and profile logging.

\section{Analysis of existing packages for geophysical well logging data processing and interpreting}

Most widely for geophysical well logging data processing and interpreting following packages are used: «SONATA» [19, 20], «Praim», «Gintel», «Pangeya», «SIAL-GIS», «Kamerton», DV-Geo, Geophysics Office, Tigress, «GeoPoisk», Techlog («Schlumberger»), LogPWin «Neftegazgeofizika» LLC. From the named software means the most spread in the territory of the Russian Federation for tasks of evaluating well technical condition and waveform acoustic logging processing are the following packages: «Praim», «Kamerton», «GeoPoisk», Techlog, LogPWin, «SONATA» [21-25]. LogPWin has different modules for processing specialized geophysical methods, but is bound to hardware made only by «Neftegazgeofizika» LLC. Techlog platform, due to variety of different modules, may be used for processing practically any logging data, but because of high price it is used in the RF only in small quantities by large oil and service companies, and it also has limitations on support of a number of domestic hardware complexes.

In table 1 given below comparative characteristics of each package for processing and interpreting logging data for purposes of technical condition evaluation and waveform acoustic logging data processing are showed.

From table 1 it is seen that among the presented software packages «SONATA» system possesses to the fullest extent all necessary functionality in the field of technical condition evaluation and waveform acoustic logging data processing. Closest its competitor in terms of functionality is Techlog system («Schlumberger»), but it is not Russian, and also, as it was stated above, poorly supports domestic hardware and is also expensive. Packages GeoPoisk» and «Praim» have enough wide functionality, but they are used mainly for processing and interpreting standard logging complexes on open bore or during reservoir management. «Kamerton» software package has developed waveform acoustic logging data processing and interpreting procedures, bur recently its evolution stopped.

\section{Development of geophysical well logging data processing and interpreting «SONATA» modular system}

«SONATA» software package is an evolution of computer software for wave signal processing «GISAkustika» и «GIS-AKTz» [26], which were intended for evaluation of well cementing quality according to acoustic logging data.

Main purpose of the software package is effective processing and interpreting of data registered by various geophysical hardware, using a variety of geophysical methods and procedures, not limited to acoustic logging only [27]. During development of «SONATA» software main attention was given to tasks of complex evaluation of well technical condition and data processing by different methods [22-25, 28, 29].

Creation of such software tools package supposes performance of works on wide range of issues related to data storage formats standardization, development of informational model and its functionality [19], including selection of data processing and interpreting methods, interface planning with software implementation, testing and introduction [2].

This variety of works was performed by «Predpriyatie "FKhS-PNG"» LLC, directed by author of the article, whose input to development of «SONATA» software package was building topical area informational model and determination of potential users conceptual requirements. 
Comparative characteristics of software packages

\begin{tabular}{|c|c|c|c|c|c|c|c|c|}
\hline \multicolumn{3}{|c|}{ Characteristics } & \multirow[t]{2}{*}{ «Praim» } & \multirow[t]{2}{*}{ «Geopoisk» } & \multirow[t]{2}{*}{ LogPWin } & \multirow[t]{2}{*}{ «Kamerton» } & \multirow[t]{2}{*}{ Techlog } & \multirow[t]{2}{*}{ «SONATA» } \\
\hline Data format support & $0-5$ & $6-10|11-20|$ & & & & & & \\
\hline \multicolumn{9}{|c|}{ Quality evaluation per industry standards } \\
\hline \multicolumn{9}{|c|}{ Wave signal preprocessing } \\
\hline \multicolumn{9}{|c|}{ Traveltime parameters determination } \\
\hline \multicolumn{9}{|c|}{ Dynamic parameters determination } \\
\hline \multicolumn{9}{|c|}{ Spectral parameter determination } \\
\hline \multicolumn{9}{|c|}{ Azimuthal anisotropy determination } \\
\hline \multicolumn{9}{|c|}{ Wellbore geometry consideration } \\
\hline \multicolumn{9}{|c|}{ Calculation of physical mechanical properties } \\
\hline \multicolumn{9}{|c|}{ Inflow coefficient evaluation } \\
\hline \multicolumn{9}{|c|}{ Step-by-step processing wizards } \\
\hline \multicolumn{9}{|c|}{ Acoustic cement bond logging } \\
\hline \multicolumn{9}{|c|}{$\begin{array}{l}\text { Acoustic cement bond logging. Well conditions } \\
\text { consideration * }\end{array}$} \\
\hline \multicolumn{9}{|c|}{ Sector acoustic cement bond logging } \\
\hline \multicolumn{9}{|c|}{ Processing well gamma defectoscope-thickness tool } \\
\hline \multicolumn{9}{|c|}{$\begin{array}{l}\text { Well gamma defectoscope-thickness tool. Well } \\
\text { conditions consideration } * *\end{array}$} \\
\hline \multicolumn{9}{|c|}{ Magnetic pulse defectoscopy processing } \\
\hline \multicolumn{9}{|c|}{ Multi-finder profiling tool processing } \\
\hline \multicolumn{9}{|c|}{ Acoustic profile logging } \\
\hline Report generation & & & & & & & & \\
\hline
\end{tabular}

Note: $\square$ - no; $\square$ - yes; $\square$ - partially; * - type of section, cement properties, well design; ** - multistring design, fluid level, eccentricity, etc.

Conceptual model development was based on analysis of data processing tasks being solved by different geophysical enterprises. Building topical area informational model supposed recognition of entities, their attributes and identification of connections between entities. Modeling and building software informational model was performed using IBM Rational Software Architect tool and UML language (Unified Modeling Language).

Advantage of using UML for informational model description is that UML is a unified graphical description language for object modeling in software development, business processes modeling, system engineering and reflecting organizational structures, which is equally understood both by topical area specialists and software developers.
That is why in the first instance comprehensive topical area analysis was performed, main conceptual requirements to the package being developed were described, system object and component models were built.

Fig. 1 shows developed system object model, which permitted to describe, within same information field, objects having diverse internal structure and composition of elements, establish complex multilevel relations between informational objects, separate both general and individual object properties.

As distinguished from object model, which reviews relations between objects, component model is an abstract presentation of system being developed, in which elements are actual components providing for implementation of system functional requirements. 


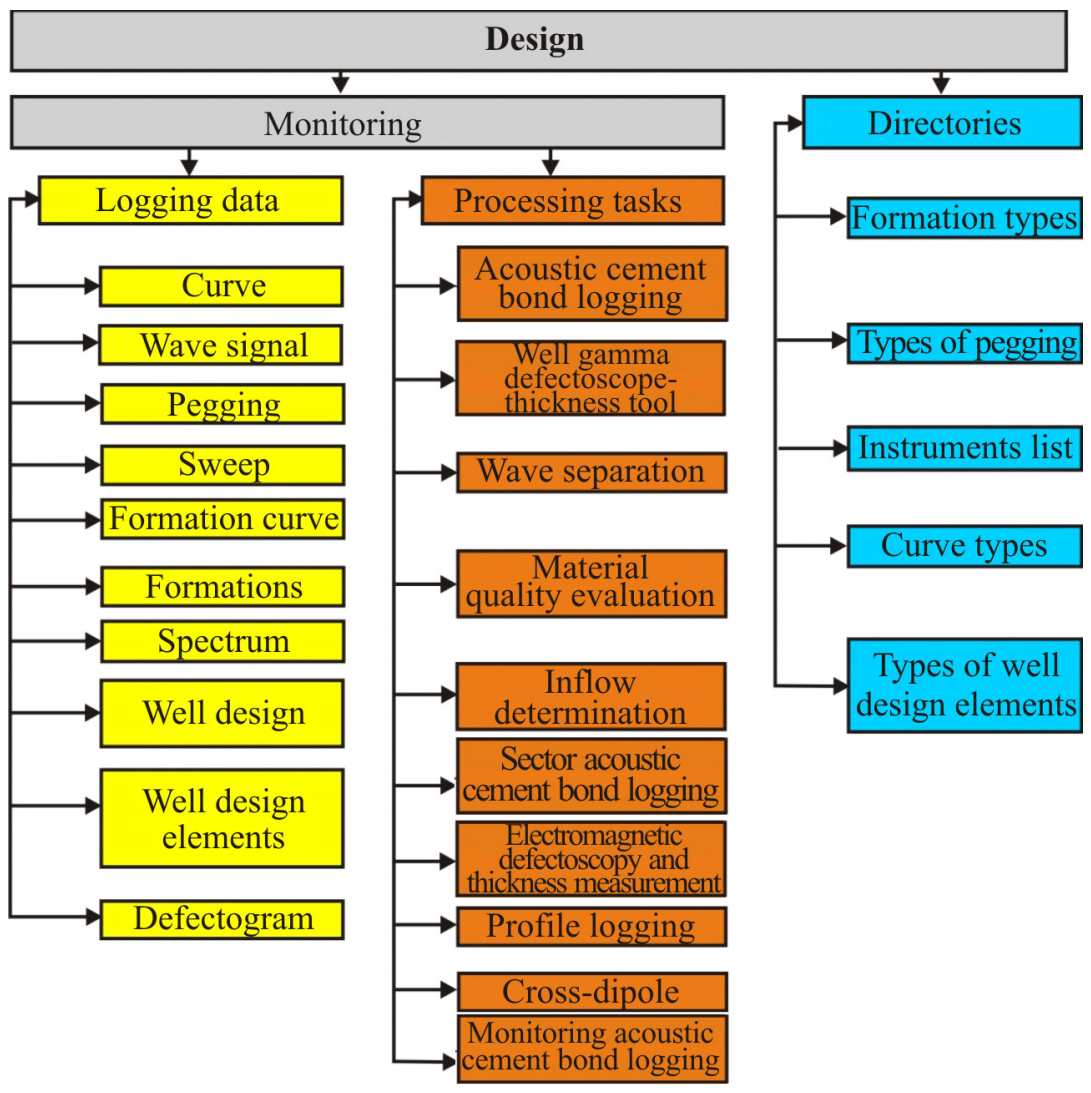

Fig. 1. Object model of «SONATA» system

For the same system many component models exist, depending on design concepts using component approach. Let us study summary model presentation level, using component functions and cluster of contracts (interfaces) between them.

Let $M[I]$ - variety of interfaces related to determination of components functions. To each $I$ it is possible to assign interface $I n$, describing interface as client-server interaction with corresponding methods and data structures. Accordingly to this, to each interface it is possible to assign pair In and Out, which let be called determining presentation In and implementing presentation Out (which corresponds to input and output interfaces). In determines conditions and purpose of interface on client side, and Out sets aspect of interface implementation on server side.

After all In and Out are determined, they could be grouped into various combinations for elements $C$. Let us see an arbitrary cluster $I n_{j}$, Out $t_{j}$. It includes simultaneously determining and implementing presentations for the same interface.

Each obtained cluster $C$ and $I$ is included into component model and is a component template.
Actually each template contains a certain variety of determining and implementing presentations of interfaces. According to these presentations actual software components templates and interfaces are further compared.

Component system model looks like

$$
\begin{gathered}
M_{\mathrm{rc}}=\left(C L_{m}\left(L m_{1}, \ldots, L m_{n}\right),\right. \\
P\left({ }_{1}, \ldots, P_{m}\right), C L_{n}\left(I n_{1}, \ldots, I n_{k}\right), D_{i},
\end{gathered}
$$

where $C L_{m}$ - components from variety of implementations in different languages $L ; P\left(P_{1}, \ldots, P_{m}\right)-$ variety of predicates corresponding to processes of assembling or configuring software tool on basis of implementations of components $C L_{m}$ and interfaces In; $C L_{n}-$ variety of components interfaces; $D_{i}$ - variety of data.

Component system model $M_{\mathrm{Kc}}$ consists of variety of functions (objects), implementations, predicates, interfaces and data.

System integrity condition is the existence for each component $C_{x}$ from $C$, having initial interface In, of component $C_{z}$ with corresponding input interface $\mathrm{CIn}_{z}$, and contract Cont $_{z}$, included in variety $C$. 


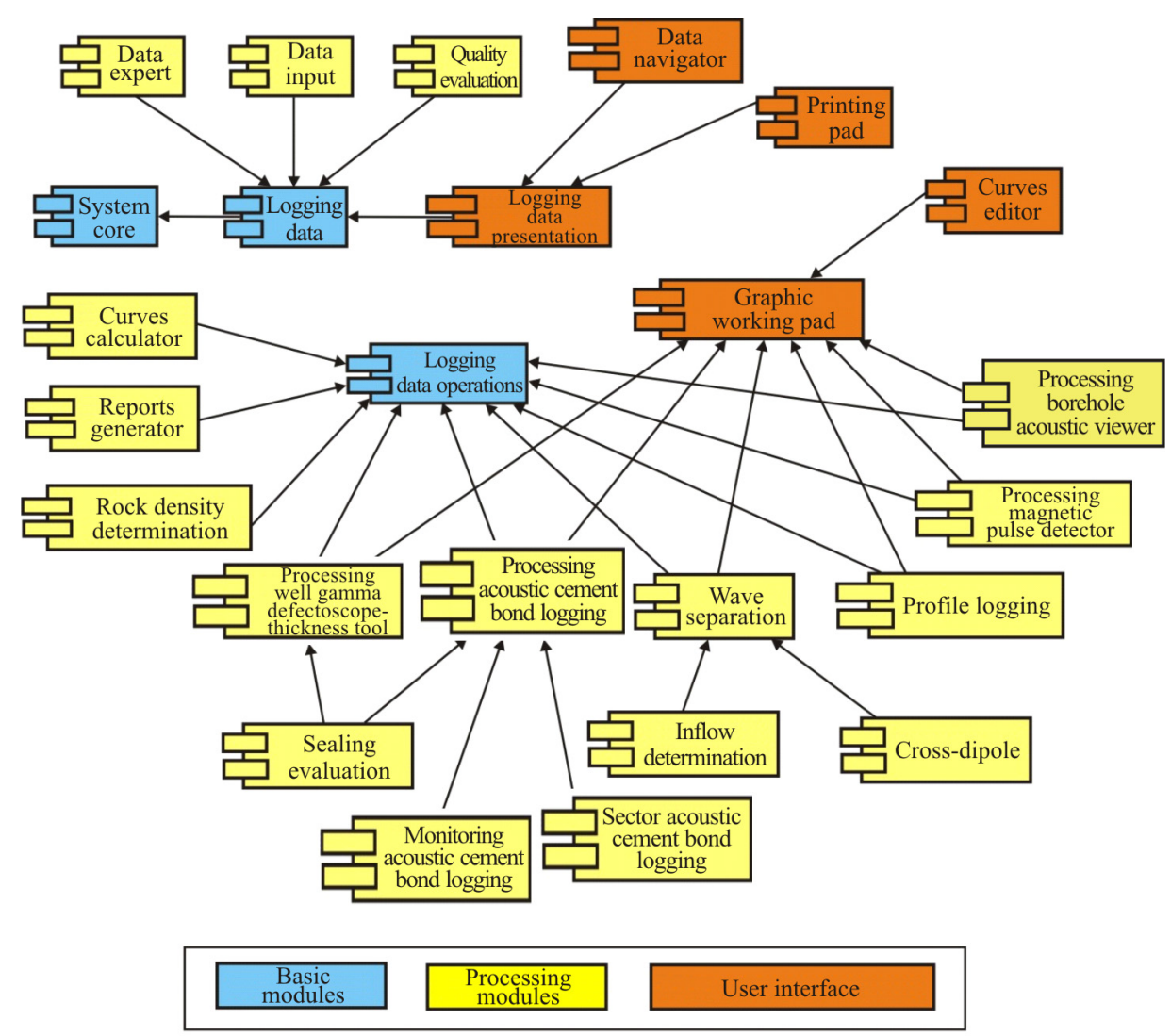

Fig. 2. SONATA system component model.

Build process $M_{\mathrm{\kappa c}}$ includes creation of component environment, detection of initial components and certain variety of interfaces according to component system functional requirements. Essence of system modeling - to present model $M_{\text {кс }}$ so that for each system element there exists a component from $C$, or it may be obtained from $C^{\prime}$ by a finite number of valid component algebra operations.

Fig. 2 shows developed component model of «SONATA» software package.

Developed «SONATA» software package includes the following main modules [30]: acoustic cement bond logging data processing and interpreting; well gamma defectoscope-thickness tool data processing and interpreting; joint interpretation of data of acoustic cement bond logging and well gamma defectoscope-thickness tool (determination of borehole annulus sealing); processing and interpreting open bore waveform acoustic logging, including modules for wave separation, obtaining traveltime, dynamic and spectrum wave characteristics, calculation of rock physical mechanical properties, determination inflow intervals according to wave signal full energy [9]; rock density determination according to complex of neutron and gamma logging; processing borehole acoustic viewer data $[9,31]$; processing magnet pulse defectoscopy data $[29,32]$; processing sector acoustics data $[23,33]$; processing cross-dipole acoustic logging [24, 34].

Main program possibilities, except above stated: data input from majority of known geophysical formats (LIS, LAS, etc.), data exports to different formats; field data quality check, including wave signal quality check; data preprocessing, correction and preparation; editing depths and data association by depth; interpreting acoustic cement bond logging and gamma-gamma cement bond logging data, their complex interpretation; processing acoustic noise logging data; borehole profile logging [35, 36]; generation of conclusion, according to results of complex interpretation, including detailed interval well performance, technical conditions, design elements location, various statistics, including that in detailed study intervals.

Workability of software usage is increased because of presence of processing wizards helping to obtain necessary results in step-by-step mode. Possibility to describe input templates permits to 
automate input of additional information on well and conclusion generation.

Consequently, developed «SONATA» software package is an effective tool for well technical condition evaluation, including complex processing and interpreting technology for a wide range of geophysical methods. Usage of single software package for evaluation of well technical condition, including universal processing of data obtained by majority of geophysical instruments, both of Russian and foreign manufacture, permitted to substantially reduce time necessary to obtain complex conclusion, meanwhile usage of data obtained at different stages of well construction, starting from studies of open bore, casing and up to studies of technical condition of production string and tubing string, permitted to significantly increase certainty and informativeness of well condition monitoring, especially in multistring intervals and difficult geology-technical conditions.

\section{Creation of utility software packages intended for logging materials compression and storage}

One of peculiarities of acoustic logging is considerably greater data volume comparing to analogue curves. Accordingly, requirements to data storage and exchange devices increase, as to processing and interpretation software. Initial data compression without losses using standard archiving programs may in average provide compression degree of $1,5-3,0$ times, which is often not enough for data transfer. Waveform acoustic logging data compression may be used for: transmitting field waveform acoustic logging material over low speed digital communication channels from remote field crews to interpretation services located at base; archiving source and processed material; data exchange between subdivisions of organizations.

Program «Szhatie VC» [37] become one of first steps on unification of formats for waveform acoustic logging data storage and presentation. Requirements to waveform acoustic logging data compression algorithm: providing for operative compressed data delivery for interpretation; error of parameters extracted from wave signal before and after compression, is within the prescribed values; performing lossy data compression after recording the whole material; archiving compression with minimal permitted distortions for the whole signal. These requirements were implemented in program «Szhatie VC», providing for: support of majority wave signal recording formats; compatibility with «SONATA» software in data formats; setting permitted signal distortion value in different areas, which permits to achieve optimal ratio «minimal useful signal distortions / maximal compression degree»; possibility of visual signal comparison before and after compression; preliminary evaluation of signal compression ratio; deletion of non-informative signal parts before primary arrivals and in signal end; packing logging curves and processed data obtained by «SONATA» software together with wave signal.

Further evolution of program was limited by its purpose to compress only waveform acoustic logging signals. Also increase of data packing / unpacking speed and reduction of errors at poor wave signal quality and low amplitude distortions at certain compression parameter settings were desirable. All that determined need of significant changes and promoted creation of new program «Szhatie GIS» $[28,38]$. For operative large volume logging data transmission it is necessary to use algorithms permitting, with minimal errors in informative source data parts, to provide for compression degree by an order higher than that of standard no-lossy compression algorithms. Source data may be split into various informative blocks, and separate error / compression degree may be set for each block. This permits to compress less informative parts with greater degree of compression, and vice versa, leave more informative parts with less distortions. Compression degree within permitted error of parameters being calculated for different methods, depending on geological-geophysical tasks being solved, may considerably vary - from several times to tens and hundreds of times.

As basis for compression method in program «Szhatie GIS» principle of data wavelet transform is used [39, 40].

Essence of the method is the following.

Source data are real number matrix $F_{m n} F_{m n}$ (geophysical data) and compression coefficient $K \in(0 ; 1)$.

Compression algorithm is the following:

- Depending on geophysical data type source data $F_{m n}$ may be subjected to preliminary transformation (without accuracy loss) $Y\left(F_{m n}\right)$. Obligatory condition for selection of transformation 
$Y$ is presence of reverse transformation $Y^{\prime}$, such, that $F_{m n}=Y^{\prime}\left(Y\left(F_{m n} F_{m n}\right)\right)$.

- Wavelet transform using two-dimensional wavelet is applied to two-dimensional data $F_{m n} F_{m n}$. Wavelet selection is made automatically depending on source data. Fitting criterion is minimization of functionality $\Psi\left(\frac{\Delta}{K}\right)$, where $\Delta$ - relative error of calculated parameters as result of compression.

Let there be source data matrix with size $m \times n$. Single-dimensional wavelet transform is applied to each matrix line. For each line we obtain matrix

$$
\left|\begin{array}{cccccc}
d_{1}^{1} & d_{2}^{1} & d_{3}^{1} & d_{4}^{1} & \ldots & d_{N / 2}^{1} \\
d_{1}^{2} & d_{2}^{2} & d_{3}^{2} & \ldots & d_{N / 4}^{2} & \\
& & \ldots & & & \\
d_{1}^{M} & d_{2}^{M} & \ldots & d_{K}^{M} & & \\
s_{1}^{M} & s_{2}^{M} & \ldots & s_{K}^{M} & &
\end{array}\right| .
$$

This matrix is transformed into array so that averaging factors appear first

$$
\begin{gathered}
s_{1}^{M} s_{2}^{M} \ldots s_{K}^{M}, d_{1}^{M} d_{2}^{M} \ldots d_{K}^{M}, \ldots \\
d_{1}^{2} d_{2}^{2} d_{3}^{2} \ldots d_{N / 4}^{2}, d_{1}^{1} d_{2}^{1} d_{3}^{1} d_{4}^{1} \ldots d_{N / 2}^{1} .
\end{gathered}
$$

From the arrays received new matrix is made with size $m \times n$. Similar actions are applied to each column in the new matrix.

- Elimination algorithm is applied to the obtained wavelet transform coefficients, i.e. all coefficient are zeroed except $N$ of the largest, where $N=m \times n(1-K)$.

- Wavelet transform coefficients are presented in form of single-dimensional real array.

- The obtained real number array is subjected to selected quantizing type, resulting in byte array.

- The obtained byte array is compressed using any standard no-lossy compression algorithm.

Signal restoration is made in opposite order, using reverse single-dimensional wavelet transform.

This developed procedure permits to adapt data compression practically for any large multidimensional data of field geophysical methods on condition that method of informative parameters extraction from source data is known.

Main characteristics of «Szhatie GIS» software package: loading logging data from various field formats; viewing loaded data in graphic form; field material quality evaluation with issuance of a conclusion; source data preprocessing and preparation; generating and filling in operator form; data export to different data exchange formats; quick field material compression and unpacking; maximal compression degree within permitted error of geophysical methods; compression and unpacking large volume logging data (hundreds of megabytes); compressing data of acoustic logging, magnetic pulse defectoscopy, well profile logging, etc. In total 211 «Szhatie GIS» workplaces are installed in different geophysical organizations.

Analysis of source data compression was performed for different logging methods (acoustic cement bond logging, wide band waveform acoustic logging, acoustic profile logging, magnet pulse defectoscopy, etc.), evaluation of informative parameters error was performed for each method before and after compression. It was shown that at permitted relative error compression degree for different geophysical methods may vary from 10 to 100 times. Average compression degree for complex of geophysical methods on evaluation of string technical condition is 20 times.

Fig. 3 shows that maximal compression degree is obtained for instruments for sector acoustic cement bond logging (MAK-SK) and magnet pulse defectoscopy (MID-K).

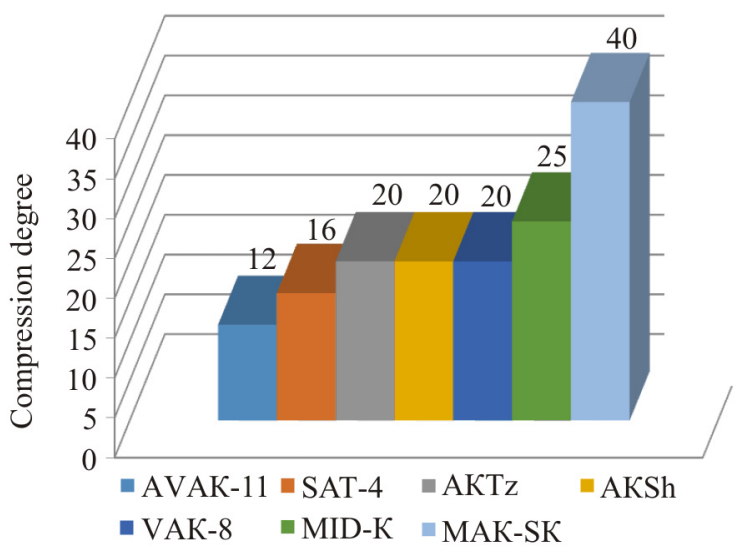

Fig. 3. Approximate compression degree for different methods and instruments within permitted error of calculated parameters

Consequently, developed method and «Szhatie GIS» program permit to solve problem of operative source large volume geophysical data transfer from well to interpretation centers.

At present over 50 different enterprises in the RF, Kazakhstan, Turkmenia, Vietnam, Serbia use the 
developed software packages «SONATA» and «Szhatie GIS» in production environment.

\section{Conclusions}

Analysis of the existing software packages revealed that their majority have these or that drawbacks, related either to long history of software evolution, when new tools do not correspond to old architecture, or with narrow specialization, when not all well methods are used.

Developed «SONATA» software package is an effective tool for evaluation of well technical condition and waveform acoustic logging data processing, including complex processing and interpreting technology for wide range of geophysical methods.
Many years of experience of using geophysical well logging data processing and interpreting modular system «SONATA» by geophysical organizations in Russia have demonstrated that the system is in demand with oilfield servicing organizations, permitting them to solve the complete range of tasks on monitoring well technical conditions, providing ergonomic interface and convenient set of tools for generation of resulting conclusions and documents.

The developed method and software for multidimensional logging data compression permit to effectively solve problem of large volume geophysical data preparation and delivery from remote field crews to interpretation centers over slow communication channels, which in turn helps to solve a pressing need of operative complex logging conclusion delivery to logging customer.

\section{References}

1. Akselrod S.M. Issledovanie profilia pritoka $\mathrm{v}$ gorizontalnykh skvazhinakh [Investigation of the flow profile in horizontal wells]. Karotazhnik, 2005, iss. 5-6, pp. 301-335.

2. Koziar V.F., Belokon D.V., Koziar N.V., Smirnov N.A. Akusticheskie issledovaniia v neftegazovykh skvazhinakh: sostoianie i napravleniia razvitiia. (obzor otechestvennykh i zarubezhnykh istochnikov informatsii) [Acoustic studies in oil and gas wells: state and directions of development. (review of domestic and foreign sources of information)]. Karotazhnik, 1999, iss. 63, pp. 10-117.

3. Belov S.V. Modelirovanie i standartizatsiia parametrov volnovogo polia $\mathrm{v}$ akusticheskom karotazhe dlia otsenki kachestva tsementirovaniia skvazhin [Modeling and standardization of wavefield parameters in acoustic logging to assess the quality of well cementing]. Ph. D. thesis. Perm, 2004.

4. Belov S.V. Otsenka kachestva dannykh VAK [Evaluation of the quality of VAK data]. Novye tekhnologii dlia neftegazovoi promyshlennosti: tezisy dokladov nauchnogo simpoziuma. Ufa, Geofizika, 2003, pp.86-88.

5. Belov S.V., Shumilov A.V. Povyshenie dostovernosti opredeleniia kachestva tsementirovaniia obsazhennykh skvazhin po dannym akusticheskoi tsementometrii [Improving the reliability of determining the quality of cementing cased wells according to acoustic cement bond log]. Vysokie tekhnologii $v$ promyslovoi geofizike. Tezisy dokladov nauchnogo simpoziuma. Ufa, Geofizika, 2004, pp.31-33.

6. Belov S.V., Gladkii S.L., Zaichkin E.V., Naugolnykh O.V., Tashkinov I.V., Shumilov A.V. Szhatie GIS [GIS compression]. Svidetelstvo o gosudarstvennoi registratsii programmy dlia EVM no. 2013611532 ot 23.01.2013. Moscow, Rospatent, 2013.

7. Belov S.V., Zaichkin E.V., Naugolnykh O.V., Tashkinov I.V., Guliaev P.N., Shumilov A.V. Modul obrabotki dannykh sektornoi akusticheskoi tsementometrii [Sector-wide acoustic cement bond $\log$ data processing module]. Svidetelstvo o gosudarstvennoi registratsii programmy dlia EVM no. 2008615595 ot 24.11.2008. Moscow, Rospatent, 2008.

8. Belov S.V., Zaichkin E.V., Tashkinov I.V., Shumilov A.V. Modul obrabotki dannykh krossdipolnogo akusticheskogo karotazha [Cross-dipole acoustic logging data processing module]. Svidetelstvo o gosudarstvennoi registratsii programmy dlia EVM no. 2014610980 ot 22.01.2014. Moscow, Rospatent, 2014.

9. Belov S.V., Zaichkin E.V., Naugolnykh O.V., Tashkinov I.V., Shumilov A.V. Modul obrabotki dannykh akusticheskogo profilemera [Acoustic profiler data processing module]. Svidetelstvo o gosudarstvennoi registratsii programmy dlia EVM no.2015616006 от 28.05.2015. Moscow, Rospatent, 2015. 
10. Belov S.V., Zaichkin E.V., Naugolnykh O.V., Tashkinov I.V., shumilov a.v. modulnaia sistema obrabotki i interpretatsii dannykh geofizicheskikh issledovanii skvazhin (sonata) [Modular system for processing and interpretation of well logging data (SONATA)]. Svidetelstvo o gosudarstvennoi registratsii programmy dlia EVM no.2004610273 ot 22.01.2004. Moscow, Rospatent, 2004.

11. Belov S.V., Zaichkin E.V., Naugolnykh O.V., Tashkinov I.V., Shilov A.A., Shumilov A.V. SonataEMDST [Sonata-EMDST]. Svidetelstvo o gosudarstven-noi registratsii programmy dlia EVM no.2008610496 ot 28.01.2008. Moscow, Rospatent, 2008.

12. Belov S.V., Tashkinov I.V., Shumilov A.V. Programmnyi kompleks "Sonata-2019" (Modulnaia sistema obrabotki i interpretatsii dannykh geofizi-cheskikh issledovanii skvazhin) [Software complex "Sonata-2019" (Modular system for processing and interpretation of well logging data)]. Svidetelstvo o gosudarstvennoi registratsii programmy dlia EVM no.2019610488 ot 11.01.2019. Moscow, Rospatent, 2019.

13. Burdin D.L., Chukhlov A.S., Shumilov A.V. Geofizicheskie issledovaniia skvazhin: registryruiushchie sistemy i oborudovanie [Well logging: recording systems and equipment]. Perm, Izdatel'stvo Permskogo gosudarstvennogo universiteta, 2010, $154 \mathrm{p}$.

14. Blatter K. Veivlet-analiz. Osnovy teorii [Wavelet analysis. Fundamentals of theory]. Moscow, Tekhnosfera, 2004, 280 p.

15. Zaichkin E.V., Shumilov A.V., Belov S.V., Tashkinov I.V. Szhatie polnogo volnovogo paketa akusticheskogo karotazha (Szhatie VS) [Compression of the full wave packet of the acoustic logging (VS compression)]. Svidetelstvo o gosudarstvennoi registratsii programmy dlia EVM no.2002612073 ot 11.12.2002. Moscow, Rospatent, 2002.

16. Driagin V.V., Ivanov D.B., Chernykh I.A., Shumilov A.V. Karotazh akusticheskoi emissii v tsikle povysheniia nefteotdachi i kontrolia istochnikov obvodneniia mestorozhdeniia [Acoustic emission logging in enhancing oil recovery and field watering sources control]. Karotazhnik, 2014, iss. 10 (244), pp.57-64.

17. Koskov V.N. Geofizicheskie issledovaniia skvazhin [Well logging]. Perm, Izdatelstvo permskogo gosudarstvennogo tekhnicheskogo universiteta, 2004, 122 p.
18. Kriuchatov D.N., Naugolnykh O.V., Tashkinov I.V., Shumilov A.V. Obrabotka dannykh akusticheskoi profilemetrii v programmnom komplekse "Sonata" [Sonic profile logging data processing by a "Sonata" software package]. Karotazhnik, 2015, iss.10 (256), pp.105-115.

19. Danilenko V.N., Danilenko V.V., Kneller L.E., Potapov A.P. Magnitoimpulsnaia defektoskopiiatolshchinometriia skvazhin - effektivnoe sredstvo informatsionnogo obespecheniia kontrolia tekhnicheskogo sostoianiia sostoianiia obsadnykh kolonn [Magnetic impulse defectoscopy-thickness gauging of wells is an effective means of information support for monitoring the technical condition of casing strings]. Karotazhnik, 2005, iss.7 (134), pp.172-185.

20. Naugolnykh O.V., Belov S.V., Shumilov A.V. podavlenie pomekh $\mathrm{V}$ massive dannykh ultrazvukovoi profilemetrii [Noise suppression in the ultrasonic profile-measurements dataset]. $\mathrm{Ka}$ rotazhnik, 2016, iss. 10 (268), pp.74-84.

21. Belov S.V., Zhulanov I.N., Sementsov A.A., Shumilov A.V. Opyt ispolzovaniia metodiki vydeleniia pritochnykh zon na mestorozhdeniiakh $\mathrm{v}$ Permskoi oblasti [Experience in the use of methods for allocating inflow zones in the fields in the Perm region]. Karotazhnik, 2000, iss.67, pp.54-57.

22. Shumilov A.V., Kaltashev S.A., Melnik V.A., Tolkachev G.M., Petukhova L.L. Opyt elektromagnitnoi defektoskopii neftianykh skvazhin s mnogokolonnoi konstruktsiei v Permskoi oblasti [Experience of electromagnetic flaw detection of oil wells with a multi-column design in the Perm Region]. Karotazhnik, 2000, iss.67, pp.28-35.

23. Naugolnykh O.V., Belov S.V., Shumilov A.V., Guliaev P.N. Osobennosti otsenki kachestva tsementirovaniia neftegazovykh skvazhin sredstvami sektornoi akustiki [Features of assessing the quality of cementing oil and gas wells by means of sector acoustics]. Novye dostizheniia $v$ tekhnike i tekhnologii gis. Tezisy dokladov nauchno-prakticheskoi konferentsii. Ufa, Geofizika, 2009, pp.244-246.

24. Belov S.V., Zaichkin E.V., Naugolnykh O.V., Tashkinov I.V., Shumilov A.V., Shilov A.A. Otsenka tekhnicheskogo sostoianiia neftegazovykh skvazhin po kompleksu geofizicheskikh metodov $\mathrm{V}$ programmnom komplekse SONATA [Evaluation of the technical condition of oil and gas wells using a set of geophysical methods in the SONATA software package]. Materialy $V$ rossiisko-kitaiskogo simpoziuma po promyslovoi geofizike. Ufa, Geofizika, 2008, pp.134-142. 
25. Potapov A.P., Danilenko V.N. Magnitoimpulsnaia defektoskopiia - tolshchinometriia neftegazovykh skvazhin [Magnetic pulse testing - oil and gas well thickness gauging]. Vesti gazovoi nauki, 2014, no.4, pp.188-195.

26. Savich A.D., Chernykh I.A., Shumilov A.V., Kostitsyn V.I. Tekhnologii geofizicheskikh issledovanii v buriashchikhsia i ekspluatatsionnykh gorizontalnykh skvazhinakh [Technologies for geophysical research in drilling and production horizontal wells]. Materialy mezhdunarodnoi nauchno-prakticheskoi konferentsii, posviashchennoi osnovateliu gorizontalnogo bureniia A.M. Grigorianu. Kazan, Slovo, 2017, pp.246-249.

27. Se M., Potapov A.P., Salnikova O.L., Shumilov A.V. Primenenie magnitoimpulsnoi defektoskopii dlia kontrolia tekhnicheskogo sostoianiia ekspluatatsionnoi kolonny [The use of magnetic pulse testing for the control of the technical condition of the production string]. Teoriia i praktika razvedochnoi $i$ promyslovoi geofiziki. Sbornik trudov po materialam mezhdunarodnoi nauchno-prakticheskoi konferentsii. Perm, Izdatelskii tsentr Permskogo gosudarstvennogo nationalnogo issledovatelskogo universiteta, 2018, pp.324-328.

28. Sementsov A.A., Zhulanov I.N., Belov S.V., Tashkinov I.V., Shumilov A.V. Trebovaniia k sovremennym sistemam obrabotki i interpretatsii materialov volnovogo akusticheskogo karotazha [Requirements for modern systems of processing and interpretation of wave acoustic logging materials]. Karotazhnik, 1999, iss.65, pp.40-45.

29. Tashkinov I.V., Shumilov A.V. Sovremennye podkhody $\mathrm{k}$ otsenke kachestva tsementirovaniia akusticheskimi metodami [Novell approaches for assessing the quality of cementing acoustic $\operatorname{logs}$ ]. Neft. Gaz. Innovatsii, 2016, no.10, pp.26-30.

30. Tashkinov I.V., Shumilov A.V. Standartizatsiia interpretatsii akusticheskogo kontrolia tsementirovaniia $\mathrm{s}$ uchetom svoistv tsementa [New approach to cbl interpretation taking into account cement properties]. Moscow, Geofizika, 2016, iss.5, pp.62-67.

31. Shumilov A.V. Novye tekhnologii skvazhinnykh elektromagnitnykh metodov $\mathrm{v}$ Permskom krae [New technologies of downhole electromagnetic methods in the Perm region]. Materialy 42 sessii mezhdunarodnogo nauchnogo seminara im. D.G. Uspenskogo. Perm, Izdatelstvo Permskogo gosudarstvennogo universiteta, 2015, pp.224-226.

32. Shumilov A.V., Belov S.V., Tashkinov I.V. Obrabotka dannykh kross-dipolnogo akusticheskogo karotazha $\mathrm{v}$ programmnom komplekse SONATA [Cross-dipole acoustic logging data processing in the SONATA software package]. Karotazhnik, 2014, iss.10 (244), pp.114-126.

33. Shumilov A.V., Zaichkin E.V. Szhatie mnogomernykh dannykh geofizicheskikh metodov issledovaniia skvazhin na osnove veivletpreobrazovaniia [Compression of multidimensional data of geophysical well survey methods based on wavelet transform]. Geofizika, 2014, iss.4, pp.46-53.

34. Shumilov A.V., Zhulanov I.N., Belov S.V., Tashkinov I.V. Opredelenie kachestva tsementirovaniia skvazhin [Determining the quality of cementing wells]. Svidetelstvo o gosudarstvennoi registratsii programmy dlia EVM no.2000610746 ot 16.08.2000. Moscow, Rospatent, 2000.

35. Assous S., Elkington P. Shearlets and sparse representation for microresistivity borehole image inpainting. Geophysics, 2018, 83(1), pp.1502-1511. DOI: 10.1190/geo2017-0279.1

36. Alford R.M. Shear data in the presence of azimuthal anisotropy. $56^{\text {th }}$ Annual International Meeting. SEG, 1986. DOI: 10.1190/1.1893036

37. Zemanek J., Angona F.A., Williams D.M., Caldwell R.L.Continuous shear wave logging. Paper U. 25th Annual Logging Symposium Transactions: Society of Professional Well Log Analysts, 1984.

38. Passey Q.R., Yin H., Rendeiro C.M., Fitz D.E. Overview of high-angle and horizontal well formation evaluation: issues, learnings, and future directions. SPWLA 46th Annual Logging Symposium, 2005.

39. Salomon D. Data compression: the complete reference. Springer, Verlag Inc., New York, 2004, 1092 p. DOI: $10.1007 / 978-1-84628-603-2$

40. Tang X., Chunduru R.K. Simultaneous inversion of formation shear-wave anisotropy parameters from cross-dipole acoustic-array waveform data. Geophysics, 1999, 64(5), pp.1502-1511. DOI: 10.1190/1.1444654 


\section{Библиографический список}

1. Аксельрод С.М. Исследование профиля притока в горизонтальных скважинах // Каротажник. - 2005. - Вып. 5-6. - С. 301-335.

2. Акустические исследования в нефтегазовых скважинах: состояние и направления развития (обзор отечественных и зарубежных источников информации) / В.Ф. Козяр, Д.В. Белоконь, Н.В. Козяр, Н.А. Смирнов // Каротажник. - 1999. Вып. 63. - С. 10-117.

3. Белов С.В. Моделирование и стандартизация параметров волнового поля в акустическом каротаже для оценки качества цементирования скважин: диссертация на соискание ученой степени кандидата технических наук. - Пермь, 2004.

4. Белов С.В. Оценка качества данных ВАК // Новые технологии для нефтегазовой промышленности: тезисы докладов научного симпозиума. Уфа: Геофизика, 2003. - С. 86-88.

5. Белов С.В., Шумилов А.В. Повышение достоверности определения качества цементирования обсаженных скважин по данным акустической цементометрии // Высокие технологии в промысловой геофизике: тезисы докладов научного симпозиума. - Уфа: Геофизика, 2004. - C. 31-33.

6. Сжатие ГИС: Свидетельство о государственной регистрации программы для ЭВМ № 2013611532 от 23.01.2013 / Белов С.В., Гладкий С.Л., Заичкин Е.В., Наугольных О.В., Ташкинов И.В., Шумилов А.В. - Москва: Роспатент, 2013.

7. Модуль обработки данных секторной акустической цементометрии: Свидетельство о государственной регистрации программы для ЭВМ № 2008615595 от 24.11.2008 / Белов С.В., Заичкин Е.В., Наугольных О.В., Ташкинов И.В., Гуляев П.Н., Шумилов А.В. - Москва: Роспатент, 2008.

8. Модуль обработки данных кросс-дипольного акустического каротажа: Свидетельство о государственной регистрации программы для ЭВМ № 2014610980 от 22.01.2014 / Белов С.В., Заичкин Е.В., Ташкинов И.В., Шумилов А.В. - Москва: Роспатент, 2014.

9. Модуль обработки данных акустического профилемера: Свидетельство о государственной регистрации программы для ЭВМ № 2015616006 от 28.05.2015 / Белов С.В., Заичкин Е.В., Наугольных О.В., Ташкинов И.В., Шумилов А.В. Москва: Роспатент, 2015.
10. Модульная система обработки и интерпретации данных геофизических исследований скважин (СОНАТА): Свидетельство об официальной регистрации программы для ЭВМ № 2004610273 от 22.01.2004 / Белов С.В., Заичкин Е.В., Наугольных О.В., Ташкинов И.В., Шумилов А.В. - Москва: Роспатент, 2004.

11. Соната-ЭМДСТ: Свидетельство о государственной регистрации программы для ЭВМ № 2008610496 от 28.01.2008 / Белов С.В., Заичкин Е.В., Наугольных О.В., Ташкинов И.В., Шилов А.А., Шумилов А.В. - Москва: Роспатент, 2008.

12. Программный комплекс «Соната-2019» (Модульная система обработки и интерпретации данных геофизических исследований скважин): Свидетельство о государственной регистрации программы для ЭВМ № 2019610488 от 11.01.2019/ Белов С.В., Ташкинов И.В., Шумилов А.В. Москва: Роспатент, 2019.

13. Бурдин Д.Л., Чухлов А.С., Шумилов А.В. Геофизические исследования скважин: регистрирующие системы и оборудование: учебное пособие. Пермь: Издательство Пермского государственного университета, 2010. - $154 \mathrm{c}$.

14. Блаттер К. Вейвлет-анализ. Основы теории. - Москва: Техносфера, 2004. - 280 с.

15. Сжатие полного волнового пакета акустического каротажа (Сжатие ВС): Свидетельство об официальной регистрации программы для ЭВМ № 2002612073 от 11.12.2002 / Заичкин Е.В., Шумилов А.В., Белов С.В., Ташкинов И.В. Москва: Роспатент, 2002.

16. Каротаж акустической эмиссии в цикле повышения нефтеотдачи и контроля источников обводнения месторождения / Дрягин В.В., Иванов Д.Б., Черных И.А., Шумилов А.В. // Каротажник. 2014. - Вып. 10 (244), - С. 57-64.

17. Косков В.Н. Геофизические исследования скважин: учебное пособие. - Пермь: Издательство Пермского государственного технического университета, 2004. - 122 c.

18. Обработка данных акустической профилеметрии в программном комплексе «Соната» / Д.Н. Крючатов, О.В. Наугольных, И.В. Ташкинов, А.В. Шумилов // Каротажник. - 2015. Вып. 10 (256). - С. 105-115.

19. Магнитоимпульсная дефектоскопиятолщинометрия скважин - эффективное средство 
информационного обеспечения контроля технического состояния обсадных колонн / В.Н. Даниленко, В.В. Даниленко, Л.Е. Кнеллер, А.П. Потапов // Каротажник. - 2005. - Вып. 7 (134). C. $172-185$.

20. Наугольных О.В., Белов С.В., Шумилов А.В. Подавление помех в массиве данных ультразвуковой профилеметрии // Каротажник. - 2016. Вып. 10 (268). - С. 74-84.

21. Опыт использования методики выделения приточных зон на месторождениях в Пермской области / С.В. Белов, И.Н. Жуланов, А.А. Семенцов, А.В. Шумилов // Каротажник. - 2000. - Вып. 67. C. 54-57.

22. Опыт электромагнитной дефектоскопии нефтяных скважин с многоколонной конструкцией в Пермской области / А.В. Шумилов, С.А. Калташев, В.А. Мельник, Г.М. Толкачев, Л.Л. Петухова // Каротажник. - 2000. - Вып. 67. C. 28-35.

23. Особенности оценки качества цементирования нефтегазовых скважин средствами секторной акустики / О.В. Наугольных, С.В. Белов, А.В. Шумилов, П.Н. Гуляев // Новые достижения в технике и технологии ГИС: тезисы докладов научно-практической конференции. Уфа: Геофизика, 2009. - С. 244-246.

24. Оценка технического состояния нефтегазовых скважин по комплексу геофизических методов в программном комплексе COНАТА / С.В. Белов, Е.В. Заичкин, О.В. Наугольных, И.В. Ташкинов, А.В. Шумилов, А.А. Шилов // Материалы V Российско-китайского симпозиума по промысловой геофизике. - Уфа: Геофизика, 2008. - С. 134-142.

25. Потапов А.П., Даниленко В.Н. Магнитоимпульсная дефектоскопия - толщинометрия нефтегазовых скважин // Вести газовой науки. 2014. - № 4. - С. 188-195.

26. Технологии геофизических исследований в бурящихся и эксплуатационных горизонтальных скважинах / А.Д. Савич, И.А. Черных, А.В. Шумилов, В.И. Костицын // Материалы Международной научно-практической конференции, посвященной основателю горизонтального бурения А.М. Григоряну. - Казань: Слово, 2017. C. $246-249$.

27. Применение магнитоимпульсной дефектоскопии для контроля технического состояния эксплуатационной колонны / М. Се, А.П. Потапов, О.Л. Сальникова, А.В. Шумилов // Теория и практика разведочной и промысловой геофизики: сборник трудов по материалам международной научнопрактической конференции. - Пермь: Издательский центр Пермского государственного национального исследовательского университета, 2018 С. $324-328$.

28. Требования к современным системам обработки и интерпретации материалов волнового акустического каротажа / А.А. Семенцов, И.Н. Жуланов, С.В. Белов, И.В. Ташкинов, А.В. Шумилов // Каротажник. - 1999. Вып. 65. - С. 40-45.

29. Ташкинов И.В., Шумилов А.В. Современные подходы к оценке качества цементирования акустическими методами // Нефть. Газ. Инновации. - 2016. - № 10. - С. 26-30.

30. Ташкинов И.В., Шумилов А.В. Стандартизация интерпретации акустического контроля цементирования с учетом свойств цемента. Москва, Геофизика, 2016. - Вып. 5. - С. 62-67.

31. Шумилов А.В. Новые технологии скважинных электромагнитных методов в Пермском крае // Материалы 42-й сессии Международного научного семинара им. Д.Г. Успенского. Пермь: Издательство Пермского государственного университета, 2015. - С. 224-226.

32. Шумилов А.В., Белов С.В., Ташкинов И.В. Обработка данных кросс-дипольного акустического каротажа в программном комплексе COНАТА // Каротажник. - 2014. - Вып. 10 (244). C.114-126.

33. Шумилов А.В., Заичкин Е.В. Сжатие многомерных данных геофизических методов исследования скважин на основе вейвлетпреобразования // Геофизика. - 2014. - Вып. 4. C. $46-53$.

34. Определение качества цементирования скважин: Свидетельство об официальной регистрации программы для ЭВМ (ГИС-АКЦ) № 2000610746 от 16.08.2000 / Шумилов А.В., Жуланов И.Н., Белов С.В., Ташкинов И.В. Москва: Роспатент, 2000.

35. Assous S., Elkington P. Shearlets and sparse representation for microresistivity borehole image inpainting // Geophysics. - 2018. - 83 (1). P. 1502-1511. DOI: 10.1190/geo2017-0279.1

36. Alford R.M. Shear data in the presence of azimuthal anisotropy $/ / 56^{\text {th }}$ Annual International Meeting. SEG, 1986. DOI: 10.1190/1.1893036

37. Continuous shear wave logging / J. Zemanek, F.A. Angona, D.M. Williams, 
R.L. Caldwell // Paper U. 25th Annual Logging Symposium Transactions: Society of Professional Well Log Analysts, 1984.

38. Overview of high-angle and horizontal well formation evaluation: issues, learnings, and future directions / Q.R. Passey, H. Yin, C.M. Rendeiro, D.E. Fitz // SPWLA 46th Annual Logging Symposium, June 26-29, 2005.
39. Salomon D. Data compression: the complete reference. - Springer: Verlag Inc., New York, 2004. 1092 p. DOI: $10.1007 / 978-1-84628-603-2$

40. Tang X., Chunduru R.K. Simultaneous inversion of formation shear-wave anisotropy parameters from cross-dipole acoustic-array waveform data // Geophysics. - 1999. - 64 (5). P. 1502-1511. DOI: 10.1190/1.1444654

Please cite this article in English as:

Shumilov A.V. Analysis of the existing and development of new software packages for processing and interpreting of geophysical well logging data. Perm Journal of Petroleum and Mining Engineering, 2019, vol.19, no.2, pp.162-174. DOI: $10.15593 / 2224-9923 / 2019.2 .6$

Просьба ссылаться на эту статью в русскоязычных источниках следующим образом:

Шумилов А.В. Анализ существующих и разработка новых программных комплексов обработки и интерпритации информации о геофизических исследованиях скважин // Вестник Пермского национального исследовательского политехнического университета. Геология. Нефтегазовое и горное дело. - 2019. - Т.19, №2. - С.162-174. DOI: $10.15593 / 2224-9923 / 2019.2 .6$ 